\title{
Mud dynamics in the Port of Zeebrugge
}

\author{
Joris Vanlede $^{1,2}$ (D) $\cdot$ Arvid Dujardin $^{1,3} \cdot$ Michael Fettweis $^{4} \cdot$ Thomas Van Hoestenberghe $^{3,5} \cdot$ Chantal Martens $^{6,7}$
}

Received: 4 June 2018 / Accepted: 2 May 2019 / Published online: 2 August 2019

(C) The Author(s) 2019

\begin{abstract}
This paper presents the mud dynamics in the harbor basin of Zeebrugge in the Southern North Sea based on an analysis of field data. Mud is typically transported into and within the harbor basin through advection of suspended particulate matter (SPM). Three important timescales have been identified. On the intratidal timescale, sediment import occurs from $2 \mathrm{~h}$ before high water to high water. Flood currents in the North Sea (directed northeastward along the Belgian coast) drive the primary gyre in the harbor mouth which is advected into the basin during rising tide. This results in water inflow near the eastern breakwater and outflow near the western breakwater. Because of sediment settling in the harbor, this results in a net import of SPM. During spring tide, the SPM flux into the harbor basin is two to four times higher than during neap tide. However, the volume of sediment removed from the port by maintenance dredging is kept constant over the spring-neap cycle, causing the amount of mud in the harbor basin to grow around spring tide conditions. On the seasonal timescale, mud volume within the harbor basin is larger in winter and reaches a minimum at the beginning of autumn. Moreover, the measured densities within the deposited mud layers are lower in winter than in summer. The most shallow point of the $210-\mathrm{kHz}$ reflector is also more shallow in winter. Finally, the profile of the interface of the mud layer in the sheltered Albert II dock is more horizontal in winter than in summer, suggesting seasonal variations in the strength of the mud layer. The question to what degree the seasonal variation of thickness and density of the fluid mud layer is related to differences in the suspended sediment input, to differences in the settling rates of suspended flocs, or to the mud consolidation rate remains open however. The data do not show a strong influence of meteorological conditions (waves, freshwater inflow) on siltation rates in the harbor basin.
\end{abstract}

Keywords Cohesive sediments $\cdot$ Harbor siltation $\cdot$ Fluid mud $\cdot$ Nautical depth $\cdot$ Zeebrugge

\section{Introduction}

The Port of Zeebrugge is subject to high siltation rates of mainly mud, and as a result, huge maintenance dredging works are mandatory (Fettweis et al. 2011, 2016). Obviously, the amount to be dredged depends on the inflow of mud into the harbor basin. Maintenance depth and

This article is part of the Topical Collection on the 14th International Conference on Cohesive Sediment Transport in Montevideo, Uruguay 13-17 November 2017

Responsible Editor: Francisco Pedocchi

Joris Vanlede

joris.vanlede@mow.vlaanderen.be

1 Department of Mobility and Public Works, Flanders Hydraulics Research, Berchemlei 115, B-2140 Antwerp, Belgium

2 Faculty of Civil Engineering and Geosciences, Delft University of Technology, Delft, The Netherlands

3 Antea Group, Buchtenstraat 9, B-9051 Ghent, Belgium dredging strategy in the port are guided by the principle of nautical depth. Pianc (1997) defines the nautical depth as the level at which physical characteristics of the bottom reach a critical limit beyond which contact with a ship's keel causes either damage or unacceptable effects on controllability and maneuverability. In Zeebrugge, the nautical bottom is defined as the density level of $1200 \mathrm{~kg} / \mathrm{m}^{3}$.

4 Operational Directorate Natural Environment, Royal Belgian Institute of Natural Sciences, Vautierstraat 29,

B-1000 Brussels, Belgium

5 Fluves, Waterkluiskaai 5, B-9040 Ghent, Belgium

6 Department of Mobility and Public Works, Maritime Access Division, Tavernierkaai 3, B-2000 Antwerp, Belgium

7 Present address: Flanders Marine Institute, Wandelaarkaai 7, B-8400 Oostende, Belgium 
Present regulations at Zeebrugge prescribe that in order to have safe maritime access to the port, the ship should have a positive under-keel clearance (UKC) of at least $10 \%$ (relative to its draft) above the nautical bottom and no more than $7 \%$ negative UKC below the mud-water interface, which is measured as the reflector of a $210-\mathrm{kHz}$ echo sounder. This means that for the accessibility of the port, both the vertical position of the $210-\mathrm{kHz}$ reflector and the $1200 \mathrm{~kg} / \mathrm{m}^{3}$ density level are important. Both levels (together with the 33-kHz reflector) are monitored regularly to steer maintenance dredging. This operational practice is the result of extensive investigations (Delefortrie et al. 2007) and is valid for the local mud and maneuvering conditions in the Port of Zeebrugge.

The sediments between the 210 and $33-\mathrm{kHz}$ reflectors consist mainly of soft or even fluid mud. Fluid mud is a high-concentration suspension that typically behaves as a non-Newtonian fluid (McAnally et al. 2016). Fluid mud is formed if the rate of sediment deposition on the bottom exceeds the dewatering/consolidation rate of these deposits. Once formed, fluid mud may flow by shear flows, gravity, and/or wave-induced streaming. If not resuspended by entrainment processes, fluid mud slowly consolidates to form bed material (McAnally et al. 2007). Fluid mud typically has a volume fraction between 0.02 and 0.13 (Mehta 1991). We refer to Mehta et al. (2014) for a description of the properties and behavior of fluid mud in relation to nautical depth estimation.

Mud is generally transported in suspension or, in some cases, as near-bed fluid mud (Winterwerp 2005; Kirby 2011). Flow exchange mechanisms at a harbor entrance are well known and include tides, horizontal entrainment, and density currents (Vanlede and Dujardin 2014).

The aim of this paper is to describe the different influencing factors and timescales that are relevant to mud dynamics in the harbor basin.

\section{Study site}

Zeebrugge is a tidal port, situated in the dynamic and turbid Belgian coastal zone. There is a gradient in turbulence and in suspended particulate matter (SPM) concentration from high outside to low inside the harbor basin. The SPM entering the harbor settles quickly within the first hundreds of meters. The port was extended seaward to its present form in the period from 1980 to 1985 , with the construction of two 4-km-long breakwaters extending about $3 \mathrm{~km}$ out to sea (see Fig. 1).

The outer port is maintained at a depth of up to $15.5 \mathrm{~m}$ below LAT (lowest astronomical tide) and the connection towards the open sea at $15.8 \mathrm{~m}$ below LAT; the port and the channels are thus substantially deeper than the nearshore area, where water depths are generally less than
$10 \mathrm{~m}$ below LAT (Fettweis et al. 2009). The analysis in this paper is limited to the outer port; the inner port (which lies behind locks) is not considered.

About 5.3 million TDM (tons dry matter) per year or $15,000 \mathrm{TDM} /$ day of mainly fine-grained sediments is dredged in the outer port (averaged over 1999-2011) and is disposed at authorized disposal sites in the North Sea, at $5-15 \mathrm{~km}$ from the harbor (Dujardin et al. 2016; Antea 2016). The sediments dredged in CDNB (the central part of the outer harbor) have an average mud content of $94 \%$ (Pieters et al. 2001).

The fluid mud layer inside the harbor basin (i.e., the layer between the 210 and $33-\mathrm{kHz}$ reflectors) has a thickness of up to $3 \mathrm{~m}$ in front of the entrance of the Albert II dock, decreasing to $2 \mathrm{~m}$ at the harbor entrance (Fig. 2). The mud-water interface has a concave-down shape which remains more or less constant in space, though its level fluctuates over time.

Typical vertical density profiles inside the harbor basin are shown in Fig. 3. Note that since the vertical density profiles and the measurements along the leading light line are not performed on exactly the same time and location, the position of the 210 (or 33) $-\mathrm{kHz}$ reflector may differ slightly between both datasets. The vertical density profiles were measured with the Navitracker instrument, which is a continuous vertical profiling gamma-ray transmission gauge. Following the limiting volume concentrations given by Mehta (1991), the limiting bulk densities of fluid mud are 1060 and $1240 \mathrm{~kg} / \mathrm{m}^{3}$. The data in Fig. 3 confirm that the material found in between the 210 and $33-\mathrm{kHz}$ reflectors has a density that corresponds with fluid mud.

The tides are semidiurnal with a mean tidal amplitude of $3.6 \mathrm{~m}$. Peak ebb and flood velocities are high in front of the harbor entrance, due to the port protruding from the coastline, which deflects ebb and flood flow close to the coast. Flood flow (directed NE) occurs from $3 \mathrm{~h}$ before HW to 2 h 40 after HW during spring tide. Peak velocity in front of the harbor entrance reaches $2.1 \mathrm{~m} / \mathrm{s}$ and occurs $40 \mathrm{~min}$ before HW during spring tide conditions (Flemish Government 2011). For deep-drafted ships, the nautical accessibility of the port is restricted to a tidal window with cross-currents less than $1.03 \mathrm{~m} / \mathrm{s}$ (or 2 knots). For LNG carriers, stricter criteria are maintained and the acceptable cross-current at the breakwaters is reduced to $0.77 \mathrm{~m} / \mathrm{s}$ or 1.5 knots (Eloot et al. 2009).

The flow field inside the harbor basin is characterized by a primary gyre (Fig. 4 shows the flow field at $1.5 \mathrm{~h}$ before HW), which is driven by the shear at the interface between water in the port and the flood flow in the North Sea. It is advected into the basin during rising tide. The primary gyre drives a smaller, secondary gyre deeper in the harbor ( $1 \mathrm{~h}$ before HW to HW), which is advected out of the basin during falling tide (HW to $2 \mathrm{~h}$ after $\mathrm{HW}$ ). 


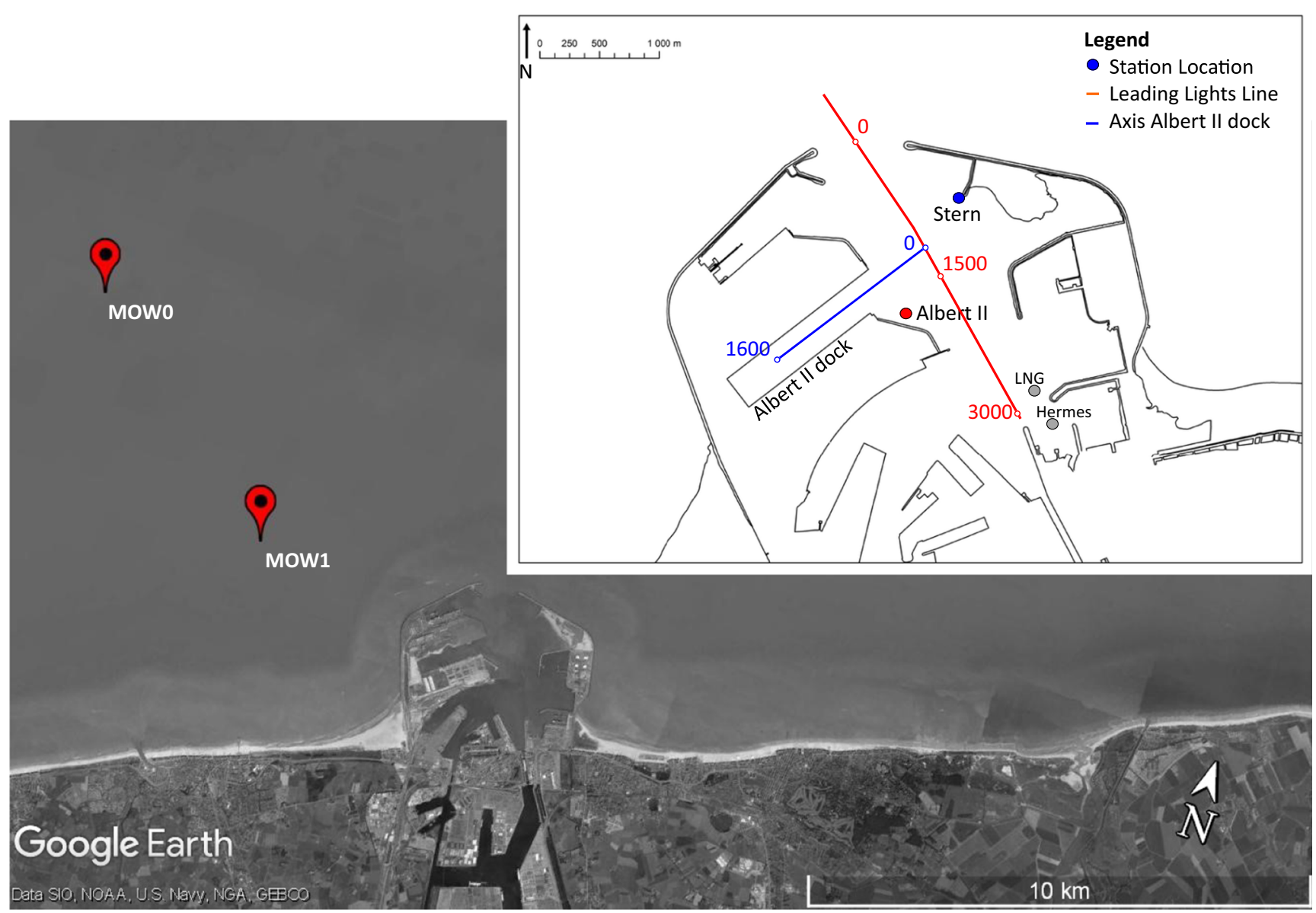

Fig. 1 Map of the Belgian coastal area (Southern North Sea) showing the measurement stations outside (MOW0, MOW1) and inside the harbor of Zeebrugge (Stern, Albert II, LNG, Hermes). The red line is the leading

\section{Materials and methods}

\subsection{Depth soundings}

Different datasets with depth soundings during the period 1999-2011 were combined for the analysis in this study. The 210 and $33-\mathrm{kHz}$ reflectors were sometimes measured as map data over larger areas in the harbor, and sometimes only as line data along the leading light line (indicated on Fig. 1). The map data was interpolated on the leading light line resulting in a combined dataset of depth along the leading light line over time.

Sounding data are used to compute changes in the volume of deposited sediments in the basin. Only those depth soundings that cover more than $50 \%$ of the leading light line are retained. Since the aim is to link observed sediment volume changes (from the soundings) with data on dredging activity and meteo conditions between two consecutive soundings, it is important that the time interval between pairs of depth soundings in the dataset remains more or less constant. Therefore, only those pairs of depth soundings are retained light line. The blue line is the axis of the Albert II dock. The background is a satellite image from Google Earth. The harbor entrance is located at $51^{\circ} 21^{\prime} \mathrm{N} 3^{\circ} 11^{\prime} \mathrm{E}$ that have a sounding interval of less than 30 days. Following these selection criteria, $80 \%$ of data is retained.

The volume change is then derived from the depth data on the leading light line by multiplying the average depth difference with the total surface area of the map data. The uncertainty in volume change when only line data is used has been estimated from the map data and is about $2 \%$ (Dujardin et al. 2016).

\subsection{Calculation of the natural depth change of the mud-water interface}

The 210-kHz reflector is considered to be the mud-water interface. A depth change of this reflector corresponds to a change of the mud volume in the harbor by natural processes and dredging works. A simple volume balance is set up to decompose the measured depth change into the natural depth change and the effect of dredging.

$\Delta h^{m}=\Delta h^{d}+\Delta h^{n}$ 
Fig. 2 The level of the mud-water interface $(210 \mathrm{kHz})$ in blue, of the $1200 \mathrm{~kg} / \mathrm{m}^{3}$ density level in brown, and of the $33-\mathrm{kHz}$ reflector in black. Data of 2007-2011. Colored bands are plus and minus one standard deviation, and min and max values. Values on $x$-axis correspond to the distance along the leading light line (indicated on Fig. 1)

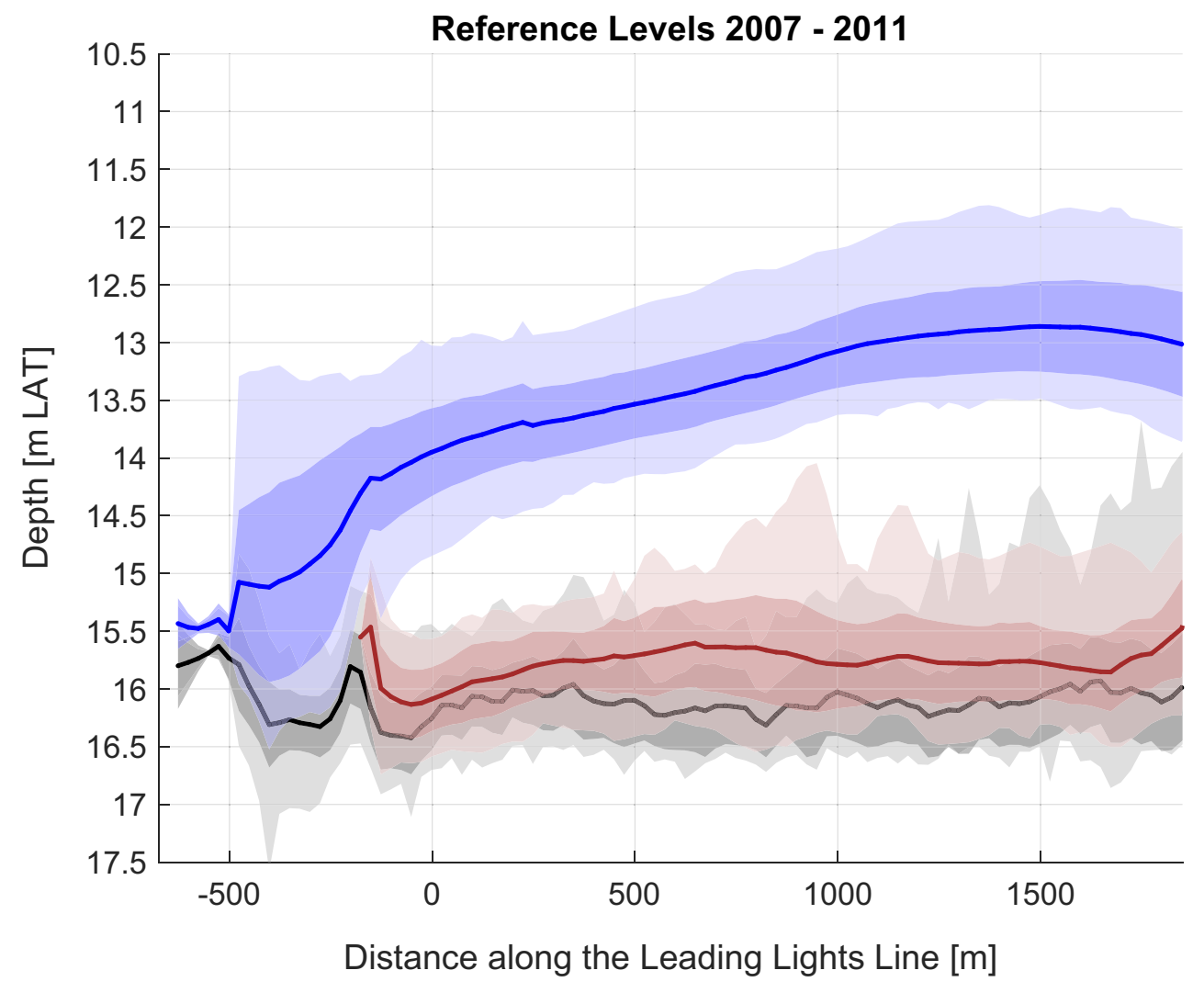

Density profiles on the leading lights line - 14/09/2012

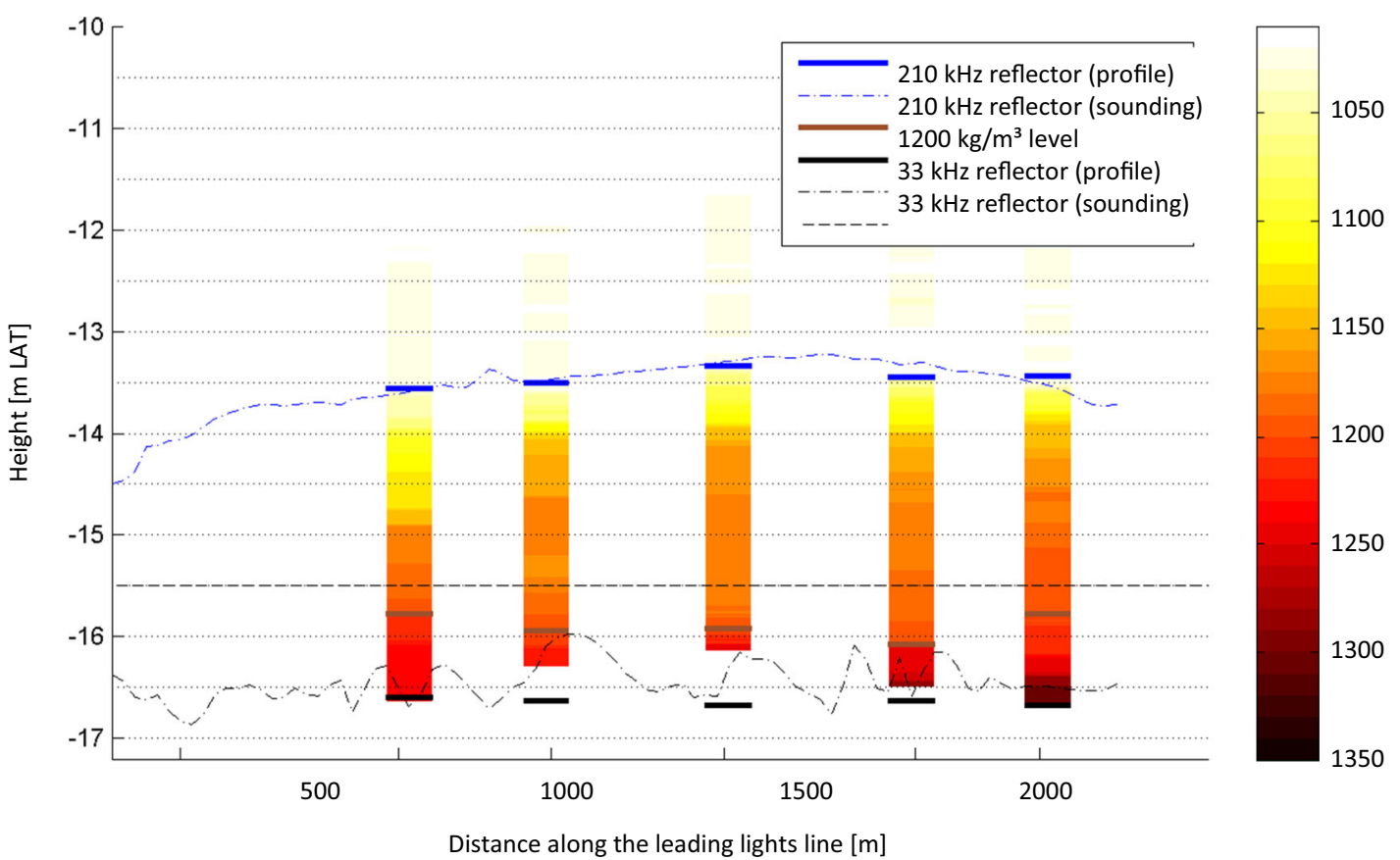

Fig. 3 Vertical density profiles measured on the leading light line. The 210-kHz reflector is indicated in blue, the 33-kHz reflector in black, and the density level of $1200 \mathrm{~kg} / \mathrm{m}^{3}$ in brown. The target maintenance depth of $15.5 \mathrm{~m}$ below LAT is indicated with a horizontal dashed line 


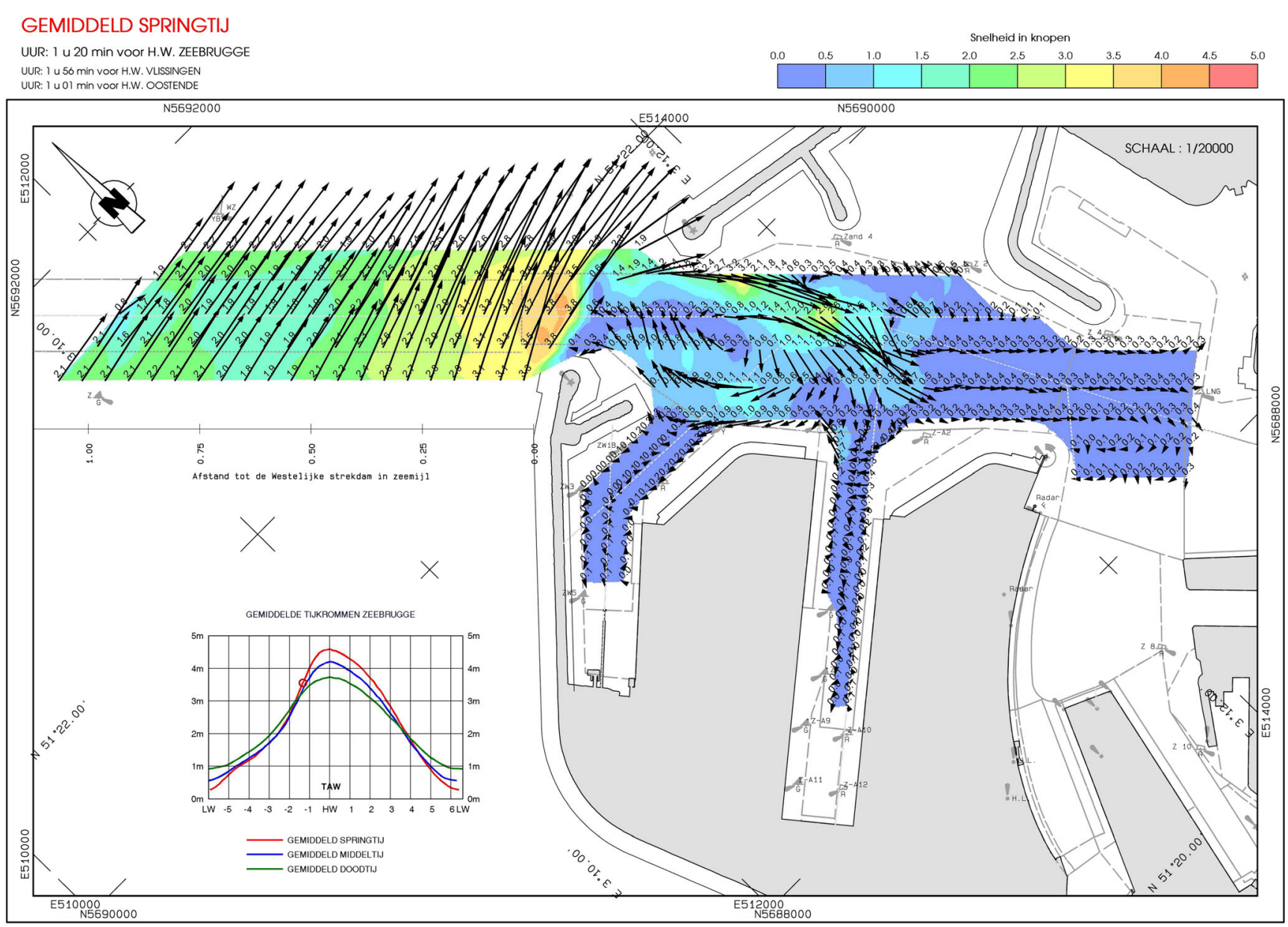

Fig. 4 Flow field (knots) in the port during spring tide and maximum flood flow (1.5 h before HW). Excerpt from the flow atlas of Zeebrugge. (Flemish Government 2011)

$\Delta h^{d}=\frac{-m^{d}\left(\rho_{g}-\rho_{w}\right)}{A \rho_{g}\left(\rho_{b}-\rho_{w}\right)}$

The natural depth change of the mud-water interface $\Delta h^{n}$ corresponds to the cumulative effect of deposition (positive sign) and resuspension and consolidation (negative sign). It is calculated from $\Delta h^{m}$ and $\Delta h^{d}$.

$\Delta h^{m}$ is the measured depth change of the mud-water interface, taken from depth soundings. A negative sign corresponds to a depth increase.

$\Delta h^{d}$ is the effect of dredging, which is calculated from the amount of dry matter dredged, $m^{d}$, with $A$ the area over which dredging was executed, $\rho_{g}$ the grain density $\left(2650 \mathrm{~kg} / \mathrm{m}^{3}\right), \rho_{b}$ the in situ bulk density, and $\rho_{w}$ the density of seawater (taken here as $1025 \mathrm{~kg} / \mathrm{m}^{3}$ ). Note that $m^{d}$, the amount of dry matter dredged, is calculated and logged directly by the dredging information system on board of the dredging vessel.

Because the in situ bulk density $\rho_{b}$ (see example in Fig. 3 ) is monitored at a lower sampling frequency than the daily dredging operations, it has to be estimated for each dredging campaign in order to calculate $\Delta h^{d}$. We choose to estimate the in situ bulk density $\rho_{b}$ of the dredged material from the bulk density of the sediment in the hopper dredger, which is measured and logged during each dredging campaign. The conversion is done based on an analysis of the relation between in situ volume concentration (IVC) and hopper volume concentration (HVC). We call this relation between volume concentrations the bulking curve. Note that theoretically, this curve has to go through $(0,0)$ because pure water in situ will be pure water in the hopper dredger. For a similar reason, the curve also has to go through $(1,1)$. Physically, dredging-related processes such as water entrainment and de-gassing of sediment will influence this relationship. Figure 5 shows the observed part of the bulking curve as a scatterplot. It is based on available density and dredging data in the harbor basin of Zeebrugge for the period 2012-2014. Each data point corresponds to one dredging campaign. The HVC is calculated from the bulk density inside the hopper dredger, as logged in the dredging information system. The corresponding IVC is calculated from the density profile closest to the dredging location and measured prior to the dredging campaign, by vertically averaging it over $1 \mathrm{~m}$, centered on the dredging depth. 
Fig. 5 Bulking curve of in situ volume concentration [-] vs hopper volume concentration $[-]$, based on measurement data from the Zeebrugge harbor basin from 2012 to 2014

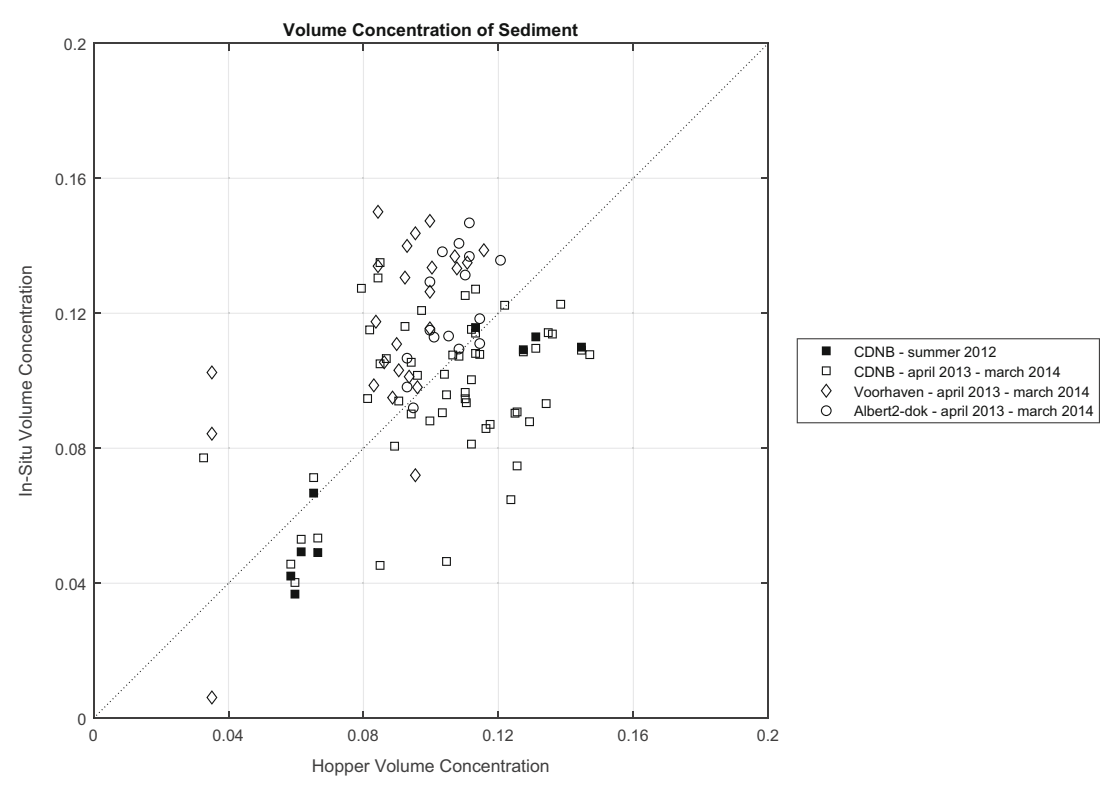

We took the reported bulk density in the hopper dredger as the estimate for the in situ bulk density $\rho_{b}$ (shown as the dotted 1:1 line in Fig. 5). The substantial scatter in the plot is likely due to the fact that the dredging campaign and the corresponding density profile are not executed at the same time and place.

\subsection{Measurements at fixed stations}

Current velocity, salinity, temperature, and SPM concentration were measured at four stations inside the harbor (Stern, Albert II, LNG, and Hermes; see Fig. 1) at about $2 \mathrm{~m}$ below LAT and about $2 \mathrm{~m}$ above the bottom. Each measuring station was equipped with a point velocimeter (Aquadopp), an OBS3+, and a CT probe (Valeport 620). At station Hermes, the instrumentation was mounted on a fixed cable, attached to the gangway of the pier and a concrete anchor at the bottom. In the other three measuring stations, the instrumentation was fixed on a steel cable between an anchor and an underwater buoy. The data were collected every $10 \mathrm{~min}$ (averaged over 60-s bursts). The measurement campaign lasted for 400 days from 14 March 2013 to 18 April 2014. More details on the instrumentation can be found in Antea (2015a).

For salinity, on average, $76 \%$ of all data points are considered usable, for SPM 69\%. The most important reasons for missing data were battery problems, bio-fouling with algae and barnacles, and technical problems with the sensors.

Because the measurement stations Stern, Albert II, and LNG are located at the edge of an area that is maintained at depth for navigation, these stations had to be installed on a sloping bed. This means that the absolute heights of the sensors may vary over time, as the instruments were taken out of the water and re-deployed every 2 to 4 weeks for checkup, cleaning, and data retrieval.
SPM concentration in the North Sea is an obvious boundary condition to mud dynamics in the port. Near-bed SPM concentration is measured with a benthic lander located about $5 \mathrm{~km}$ northwest of the port (MOW1) (see Fig. 1).

\subsection{SPM concentration measurements from ADCP transects inside and outside the harbor}

From March 2013 to April 2014, 113 longitudinal transects have been sailed in the harbor with the research vessel RV Belgica (see Fig. 1 for the location of the transect). The acoustic backscatter recorded from a hull-mounted 300-kHz ADCP was converted to SPM concentration (Thorne et al. 1994; Holdaway et al. 1999). Example SPM data is shown in Fig. 8.

The conversion from acoustic backscatter to SPM concentration was done as follows. During an 8-h period, water samples and vertical profiles have been collected inside and outside the harbor using a CTD, an OBS, and a LISST 100X. The water samples have been analyzed for SPM, particulate organic matter (POC), and chlorophyll concentration. The OBS signal was converted into SPM concentration through a linear relationship obtained after filtering and weighing of water samples. The relationship between the acoustic backscatter (in $\mathrm{dB}$ ) and the SPM concentration was established using the SPM concentration derived from the OBS profiles. One relationship was applied to the whole dataset. The acoustic backscatter signal depends strongly on particle size and density however. The samples collected for calibration may not represent SPM properties in all 113 transects. Due to the rapid settling of sediment inside the harbor, strong gradients are expected in the size and composition of the remaining SPM. The SPM inside the harbor has larger floc sizes and lower densities with higher organic content, while outside the 
harbor, the SPM occurs as bio-mineral aggregates as described by Fettweis and Lee (2017). The echo intensity of the backscattered acoustic signal should therefore only be seen as an estimate of the SPM concentration.

It should be noted that only a low correlation $\left(R^{2}=\right.$ 0.35 ) is found between the SPM concentrations from the bottom OBS sensor at station Albert II and the corresponding SPM concentration from the ADCP transects (Antea 2015b). The SPM concentration derived from the ADCP data is typically two times higher than the one derived at the fixed measurement station, with significant scatter between the two datasets. The scatter could be related to different calibrations to convert the acoustic and the optical backscatter to SPM and to spatial variation of the SPM concentration. Note that we only use the SPM concentration from the ADCP data to establish the intratidal timing; we do not use the absolute values of sediment concentrations.

\subsection{Freshwater inflow into the port and salinity}

Freshwater discharge can contribute significantly to the siltation rate of a harbor. The relative contribution is site-specific however (Winterwerp and de Boer 2016). Freshwater is discharged into the harbor through the Leopoldkanaal and the Schipdonkkanaal. Both canals discharge gravitationally during low water. The daily averaged total freshwater discharge of both canals has a positively skewed distribution with a low median of $1.1 \mathrm{~m}^{3} / \mathrm{s}$ and a maximum of $80 \mathrm{~m}^{3} / \mathrm{s}$ (Dujardin et al. 2016). Dry periods with no freshwater inflow occur typically during summer and autumn conditions. Because freshwater can only be discharged around low water, the freshwater distribution is tidally modulated. Vertical salinity profiles are available at 27 locations inside the harbor (IMDC et al. 2011). The profiles were measured during 44 campaigns in the period 2007 to 2008.

\subsection{Wave data}

Wave data from the directional wave buoy at Bol van Heist was analyzed for the period 1999-2011. The wave direction typically varies from north to west-southwest. The significant wave height has a log-normal distribution with a median value of $0.6 \mathrm{~m}$ in summer and $0.75 \mathrm{~m}$ in winter.

\subsection{Data classification and ensemble analysis}

The time series of SPM concentration and current velocity measured inside the harbor are split up into individual tidal cycles and interpolated with a 10-min interval on a local time axis relative to the moment of $\mathrm{HW}$. The tidal cycles are grouped in three classes, according to the tidal amplitude at Zeebrugge, and labeled as spring, mean, or neap tide, respectively. All tidal cycles in a certain tidal class are combined in an ensemble, and the average and standard deviation are calculated on the local time axis (see Fig. 7). This ensemble analysis (or phase averaging) is used to gain insight in the intratidal (Section 4.3.1) and spring-neap modulation (Section 4.4.1) of the SPM concentration signal.

\section{Results and discussion}

\subsection{Influence of freshwater inflow on sediment import}

The salinity in the lower half of the water column inside the harbor basin shows no observable vertical gradient. During periods of high freshwater discharge $\left(>10 \mathrm{~m}^{3}\right)$, the water column inside the harbor becomes vertically stratified near the surface, with a thin layer $(\sim 1 \mathrm{~m})$ of freshwater. This stratification typically dissipates through mixing in 6 to $8 \mathrm{~h}$.

Freshwater import into the harbor may induce a density current into the harbor basin in the lower half of the water column. The velocity of the freshwater front on top of the saline water in the harbor can be estimated following Kranenburg (1998) as

$c=\sqrt{\varepsilon g \frac{a_{1}}{a} \frac{\left(a-a_{1}\right)\left(2 a-a_{1}\right)}{\left(1-\beta_{1}\right) a_{1}+\left(1+\beta_{1}\right) a}}$

with $\varepsilon$ the relative density difference $\Delta \rho / \rho, a_{1}$ the height of the freshwater front, $a$ the water depth, and $\beta_{1}$ a loss term (between 0 and 1). Note that in case $a_{1}=a / 2$ and $\beta_{1}=0$, this formulation collapses to the relation $c=0.5 \sqrt{\varepsilon g a}$, which is often used to describe lock-exchange flow. A freshwater front of $1-\mathrm{m}$ height in a water column of $15 \mathrm{~m}$ has a propagation speed of $0.6 \mathrm{~m} / \mathrm{s}\left(\beta_{1}=0\right)$, which would (assuming no net water exchange) induce a depth averaged return flow of only $0.05 \mathrm{~m} / \mathrm{s}$ into the harbor. This is consistent with an analysis of the velocity field around the harbor entrance of Zeebrugge which shows that water exchange due to density currents is small compared with the total exchange flow (Vanlede and Dujardin 2014).

The direct import of sediment in suspension via the Leopoldkanaal and the Schipdonkkanaal is negligible. If we assume an average SPM concentration of $50 \mathrm{mg} / \mathrm{l}$ in the canals and a median freshwater discharge of $1.1 \mathrm{~m}^{3} / \mathrm{s}$, then the import of sediments by the canals represents only $0.05 \%$ of the total sediment import.

We therefore reject the hypothesis that freshwater inflow into the harbor influences sediment import (either through a density current or through a sediment load in suspension). This is confirmed by the fact that no correlation is found between the 
natural depth change of the mud-water interface (see Section 3.2) and the freshwater discharge (Dujardin et al. 2016).

\subsection{Influence of wind and wave climate on sedimentation}

The natural depth change of the mud-water interface (see Section 3.2) is binned according to the mean wave direction and the peak wave height at station Bol van Heist. The P95 significant wave height is used as a proxy for peak wave height.

In Fig. 6, we only find a weak positive correlation $\left(R^{2}=0.35\right)$ between the peak wave height and the natural depth change of the mud-water interface (calculated with the method described in Section 3.2). The mud-water interface rises between 1 and $3 \mathrm{~cm} /$ day if the P95 significant wave height is larger than $1.19 \mathrm{~m}$. Note that our results are in contrast to Lanckneus and Van Lancker (2001), who found higher siltation during periods of lower wave heights. The difference between both findings can be related to the low correlation between depth change and wave conditions, which can make the sign of the (weak) correlation dependent on the period that is analyzed.

Following a similar methodology, we also investigated the influence of wind climate on sedimentation, but found no meaningful correlation.

\subsection{Intratidal variation}

\subsubsection{Intratidal variation of SPM concentration at fixed stations}

Figure 7 shows the ensemble analysis of both SPM concentration and current velocity, measured with the lower sensors at stations Stern and Albert II during spring tide (ensembles for neap and mean tide show the same phasing). SPM concentration peaks $1 \mathrm{~h}$ before HW at station Stern and $50 \mathrm{~min}$ later at Albert II. A cross-correlation analysis of the complete time series at Stern and Albert II confirms that the SPM concentration signal at Albert II is 50 min delayed from the signal at Stern. This delay is explained in terms of the time of advection of SPM from station Stern to station Albert II by the primary gyre in the harbor basin.

A 50-min travel time over a 1000-m trajectory corresponds to an average advection velocity of $0.33 \mathrm{~m} / \mathrm{s}$. The peak SPM concentration near the bottom is higher deeper inside the harbor basin at Albert II (900 mg/l) than at Stern $(600 \mathrm{mg} / \mathrm{l})$, even though the velocity at that time is lower at Albert II. This result can be understood in terms of vertical settling during advection between stations Stern and Albert II. This also suggests that local resuspension is not the dominant process that determines sediment concentration in the Albert II dock.

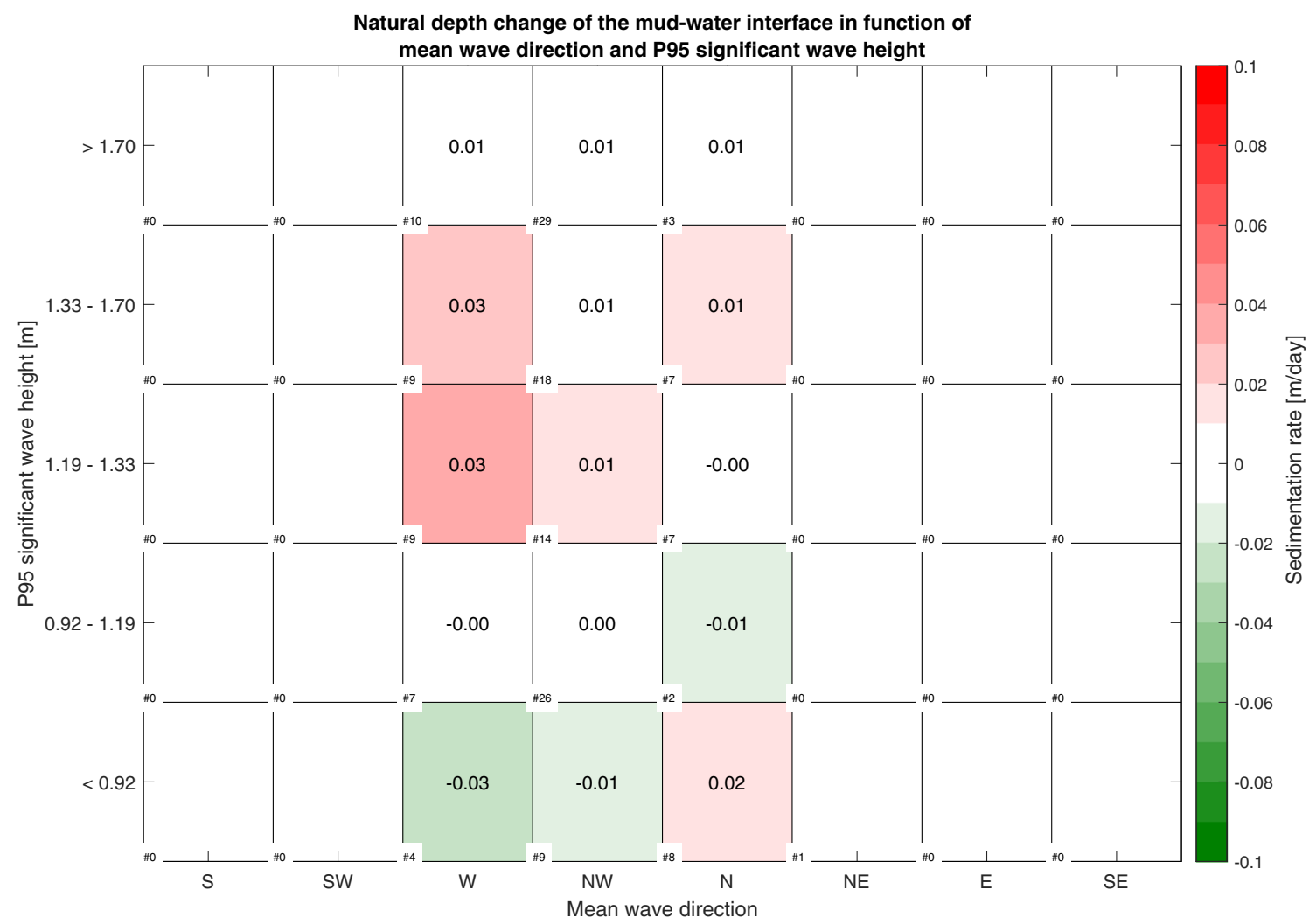

Fig. 6 Natural depth change of the mud-water interface [m/day] classified according to mean wave direction and P95 significant wave height. The number of datapoints is shown in the lower left corner of each cell. Bins of less than three datapoints are represented by empty cells 
Fig. 7 Ensemble analysis for SPM (top) and velocity (bottom) measured during spring tide conditions with the lower sensors of stations Albert II (in red) and Stern (in blue). The full line is the median; the shaded area lies between the 20th and 80th percentile
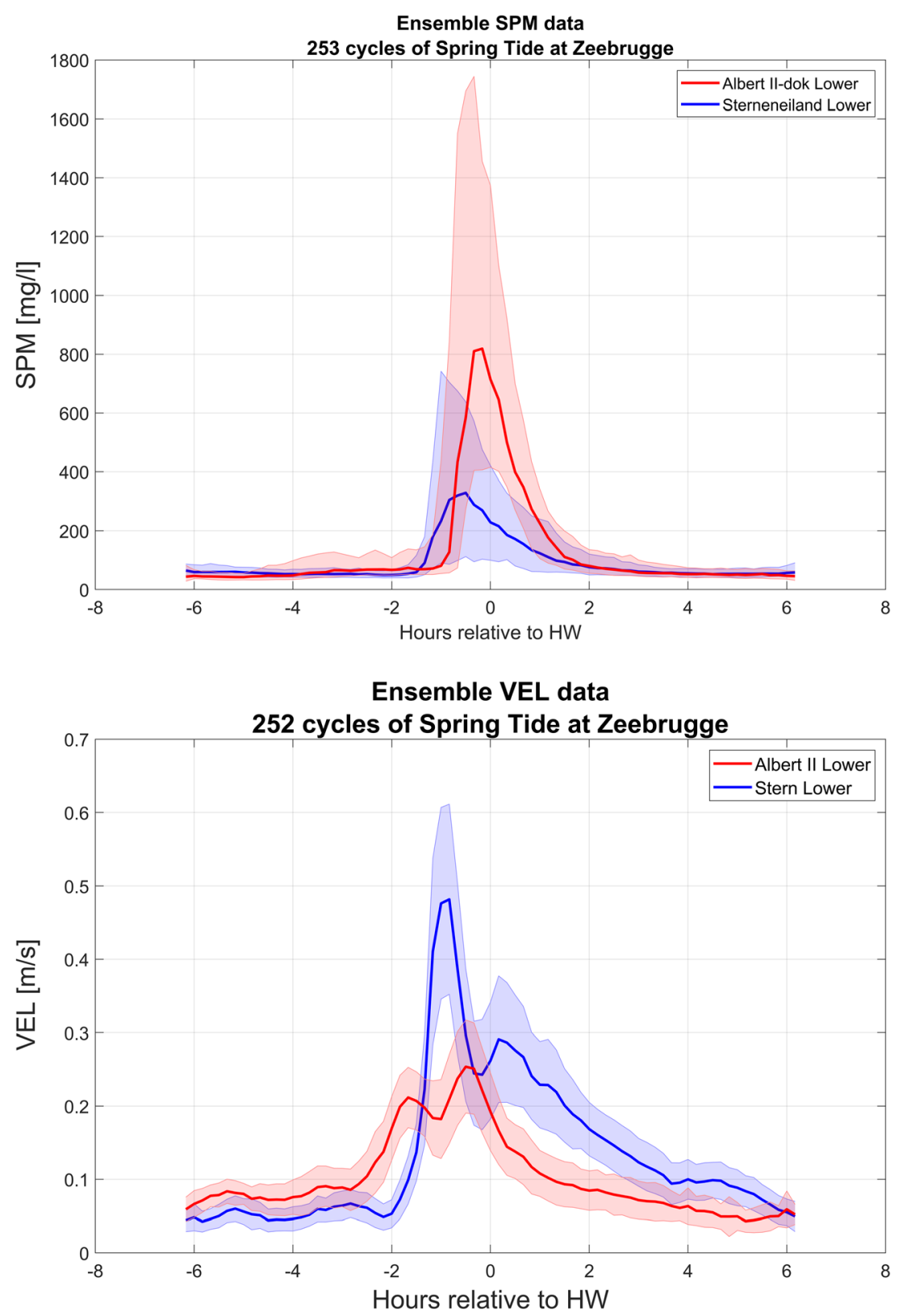

The peak SPM concentration at the upper sensor, however, is similar at both stations $(350 \mathrm{mg} / \mathrm{l})$. This suggests that a slower settling fraction determines the sediment concentrations in the upper part of the water column.

These results are consistent with the analysis of the flow exchange mechanisms between a harbor basin and the open sea, applied to Zeebrugge by Vanlede and Dujardin (2014). They concluded that horizontal exchange is the most important component of the sediment import at the harbor mouth of Zeebrugge and that most of the sediment import occurs from $2 \mathrm{~h}$ before high water to high water. In that timeframe, flood currents in the North Sea (directed northeastward along the Belgian coast) drive the primary gyre in the harbor mouth, which is advected into the basin during rising tide. This results in water inflow near the eastern breakwater (close to the measurement station Stern; see Fig. 4) and outflow near the western breakwater. Because of sediment settling in the harbor, the sediment concentration in the outflowing water is lower than that in the inflowing water, which results in a net import of SPM.

\subsubsection{Intratidal variation of SPM concentration from ADCP transects}

Figure 8 shows four vertical profiles of SPM concentration, measured during one tidal cycle in June 2013 (see 


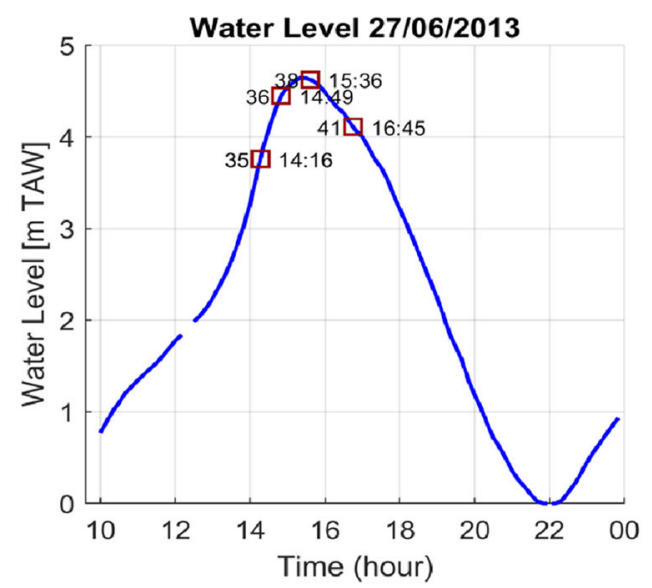

Water levels in Zeebrugge during ADCP transects 27/06/2013

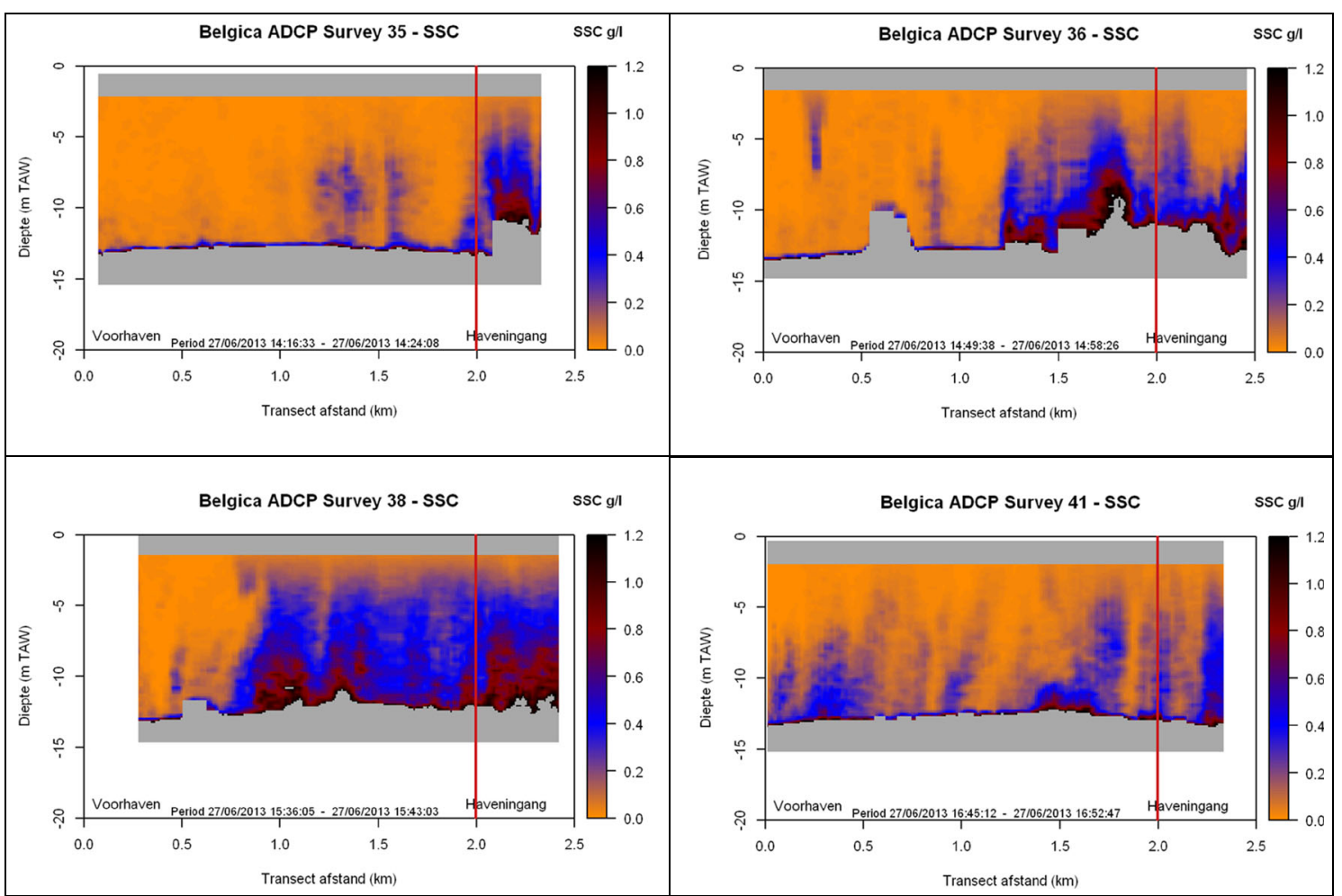

Fig. 8 SPM from ADCP backscatter, measured on 27 June 2013 on a longitudinal transect in the port. The port entrance (indicated with a red line) is to the right of each panel. Phase during the tidal cycle clockwise from top left: $1 \mathrm{~h}$ before HW (survey 35), 30 min before HW, 30 min after HW, 2 h after HW (survey 41)

$500 \mathrm{~m}$. Two hours after HW (bottom left panel), the SPM concentrations in the water column are lower, because of settling and deposition.

The intratidal phasing of the vertical SPM profile is consistent with the tidal modulation in SPM concentration measured at stations Albert II and Stern (see Section 4.3.1). The sequence of vertical profiles of SPM concentration in Fig. 8 confirms that the bulk of the SPM is transported into the harbor through advection around HW and that the most important transport occurs in the bottom half of the water column. 
Table 1 Spring-neap variation in net sediment influx to the Port of Zeebrugge

\begin{tabular}{llll}
\hline Source & $\begin{array}{l}\text { Net sediment influx-neap tide } \\
{[\text { TDM/day] }}\end{array}$ & $\begin{array}{l}\text { Net sediment influx-spring } \\
\text { tide [TDM/day] }\end{array}$ & Ratio spring/neap \\
\hline Claeys et al. (2001) & 1590 & 6400 & 4.0 \\
Dujardin et al. (2009) & 3454 & 13,880 & 4.0 \\
IMDC (2011) & 834 & 1468 & 1.8 \\
Average & 1986 & 7357 & 3.0 \\
\hline
\end{tabular}

\subsection{Spring/neap cycle}

\subsubsection{Spring/neap variation in sediment import}

The amount of sediment that enters the harbor in suspension have been estimated from ADCP measurements executed on a transect across the harbor entrance, e.g., Claeys et al. (2001). In IMDC (2010), two measurement campaigns are described that have been executed during spring and neap tide conditions. In the bottom blanking zone of the ADCP, IMDC (2010) extrapolated the vertical SPM profiles towards the bed. Dujardin et al. (2009) used the same ADCP dataset, but used concurrent turbidity measurements close to the bottom to derive the SPM concentrations close to the bed. The resulting estimates for the total sediment import are five to ten times higher than in IMDC (2010). This result underlines the importance of near-bed data for estimating total sediment fluxes.

Table 1 summarizes the different estimates of the springneap modulation in the net sediment influx into the harbor. On average, sediment import into the harbor during spring tide is two to four times higher than during neap tide.
This is consistent with the spring-neap variation of SPM concentrations outside the harbor, measured with a benthic lander at MOW1 (Fettweis and Baeye 2015). De Maerschalck et al. (2015) have shown that the peak SPM concentrations at $2.2 \mathrm{~m}$ above the bottom (mab) are up to be three times higher during spring than during neap tide.

This is also consistent with the spring-neap variation of peak SPM concentrations observed near the entrance of the harbor. An ensemble analysis of the spring-neap variation of SPM at station Stern (Fig. 9) shows peak SPM concentrations prior to high water, i.e., at the moment of highest sediment import, that are four times higher during spring tide than during neap tide. The intratidal phasing of the SPM peak does not change over the spring-neap cycle. No significant spring-neap variation was found however at stations deeper inside the harbor (LNG and Hermes).

Based on the flow atlas (Flemish Government 2011), we can determine that the maximum velocity near the eastern breakwater during inflow is about two times higher during spring than during neap tide. The spring/neap variation in sediment import is therefore a combination of higher SPM concentrations and higher velocities during spring tide.
Fig. 9 Spring (red) to neap (in yellow) variation of SPM during a tidal cycle at station Stern. The full line is the median; the shaded area lies between the 20th and 80th percentile

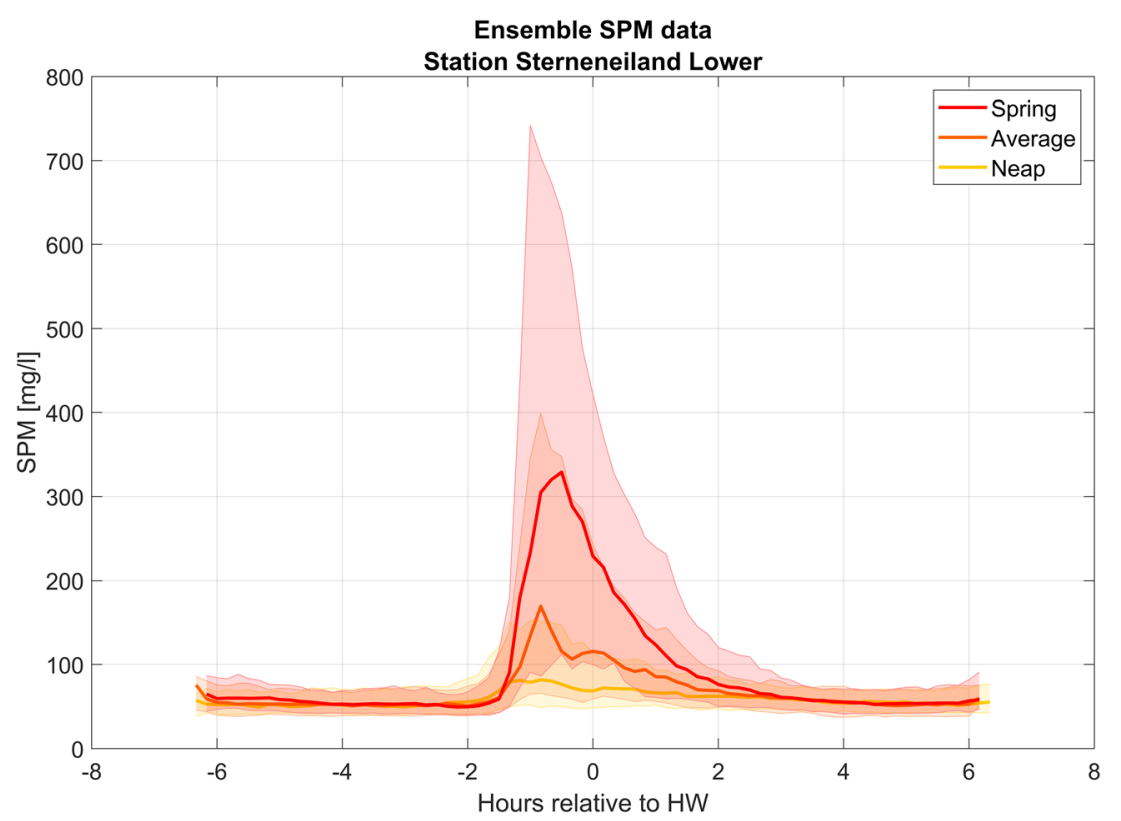


Sediment import, SPM concentrations in the Belgian nearshore, and SPM concentrations inside the harbor close to the entrance all co-vary over a spring-neap cycle with similar relative amplitude and phasing. This supports the hypothesis of sediment import through advection. The SPM concentrations at the landward end of the harbor do not show this spring/neap variation however, which suggests that they are governed by different processes, such as resuspension (due to ship movements or dredging activity) or gravitational flow of mud layers inside the harbor.

\subsubsection{Influence on the mud-water interface}

Averaged over 1 month, the total mass dredged is equal to the sediment import. There is, however, no spring-neap variation in the daily dredging amounts (Dujardin et al. 2016), which means that the sediment extraction from the port does not follow the modulation in sediment import. As a result, the level of the mud-water interface in Albert II dock typically rises up to $15 \mathrm{~cm} /$ day during spring tide conditions and falls 5 to $10 \mathrm{~cm} /$ day during neap and mean tide conditions.

\subsection{Seasonal variation}

SPM concentrations inside the harbor have a significant seasonal variation in all fixed measurement stations, with lower SPM concentrations in spring and summer and higher in autumn and winter (Dujardin et al. 2016). Figure 10 shows the relative frequency distribution of SPM values in station Albert II in summer and winter conditions. This figure illustrates how the median SPM is higher in winter than in summer, both for the top and the bottom sensor. There is also a higher probability of higher SPM values $(>100 \mathrm{mg} / \mathrm{l})$ in winter in the bottom sensor.

The seasonality inside the harbor is consistent with the seasonality in SPM concentration at the surface and in the water column that is observed in the Belgian nearshore area (Fettweis et al. 2007; Fettweis and Baeye 2015). Seasonality of surface SPM in the North Sea at stations MOW0 (Wandelaar) and Vlakte van de Raan was quantified from satellite imagery. Surface SPM concentration at these stations is about half the yearly average for spring and summer and $70 \%$ higher in winter. The bottom SPM concentration from the benthic lander located at MOW1 shows a comparable seasonal variation, with peak SPM concentrations at $2.2 \mathrm{mab}$ about twice as high in autumn-winter than in spring-summer (De Maerschalck et al. 2015).

Figure 11 shows the seasonal variation of the most shallow point of the $210-\mathrm{kHz}$ reflector along the leading light line (location in Fig. 1). As described Section 1, the height of the $210-\mathrm{kHz}$ reflector is part of the local definition of the nautical bottom. The minimum height (or most shallow point) along

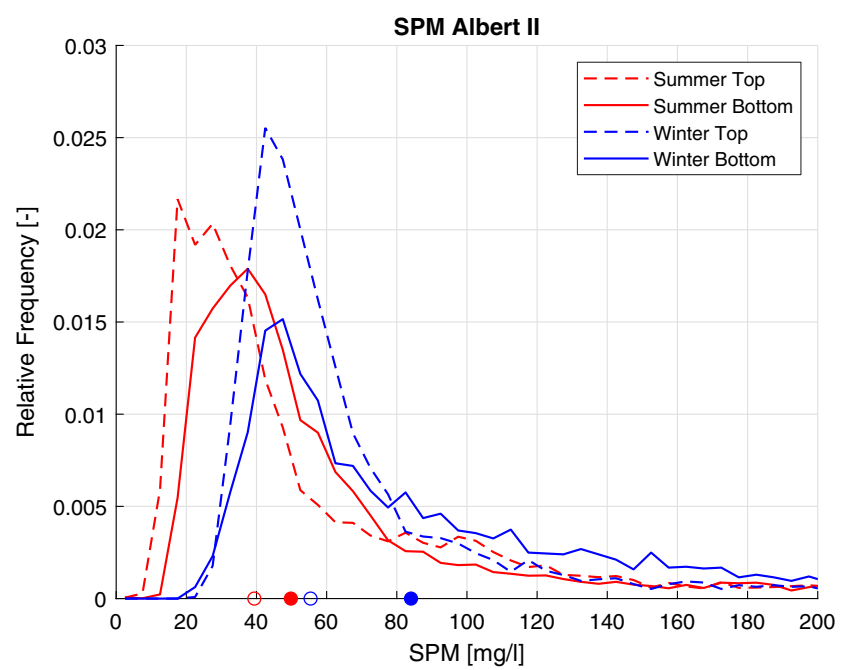

Fig. 10 Relative frequency distribution of SPM at station Albert II in winter (in blue) and summer (in red). Top sensor in dashed line, bottom sensor in solid line. Median values are indicated with a circle on the $x$-axis (a full circle for the bottom sensor and an outlined circle for the top sensor)

the leading light line is thus an obvious statistic to monitor. If the $210-\mathrm{kHz}$ reflector rises too high somewhere in the basin, nautical accessibility is hindered. Figure 11 clearly shows a seasonal variation in this statistic, with the top of the $210-\mathrm{kHz}$ reflector being more shallow in winter.

Also, the density profiles show a lower density of the sediment layers in winter than in summer. In summer, $65 \%$ of sediment in between the $210-\mathrm{kHz}$ and $33-\mathrm{kHz}$ reflectors has a density below $1.18 \mathrm{~g} / \mathrm{l}$, whereas in winter, that number increases to $80 \%$ (Antea 2015b). The temperature of the pore water might play a role here. It affects the viscosity of the pore water, and the permeability is inversely proportional to viscosity (Merckelbach and Kranenburg 2004). For winter conditions, this means a higher viscosity, a lower permeability, and thus a slower consolidation in winter.

Minimum depth of the $210 \mathrm{kHz}$ reflector along the

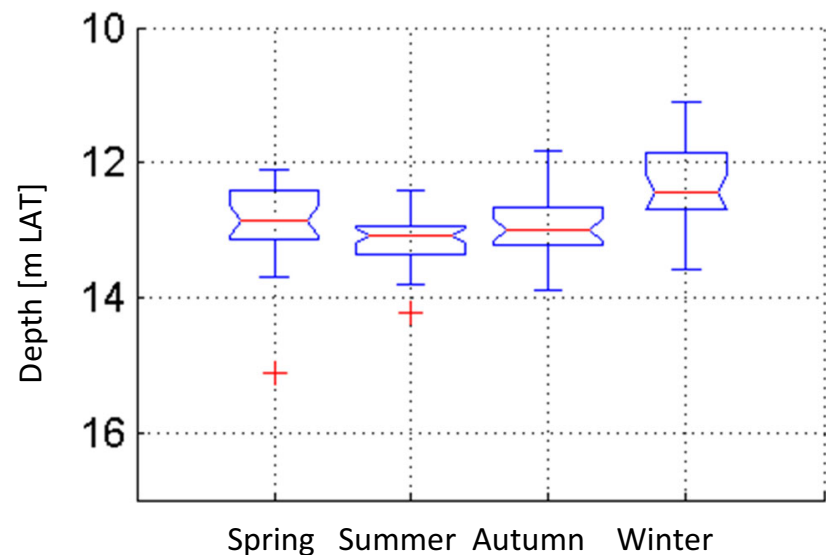

Fig. 11 Seasonal variation of the minimum depth along the leading light line of the 210-kHz reflector in CDNB. Data from 2007 to 2011 

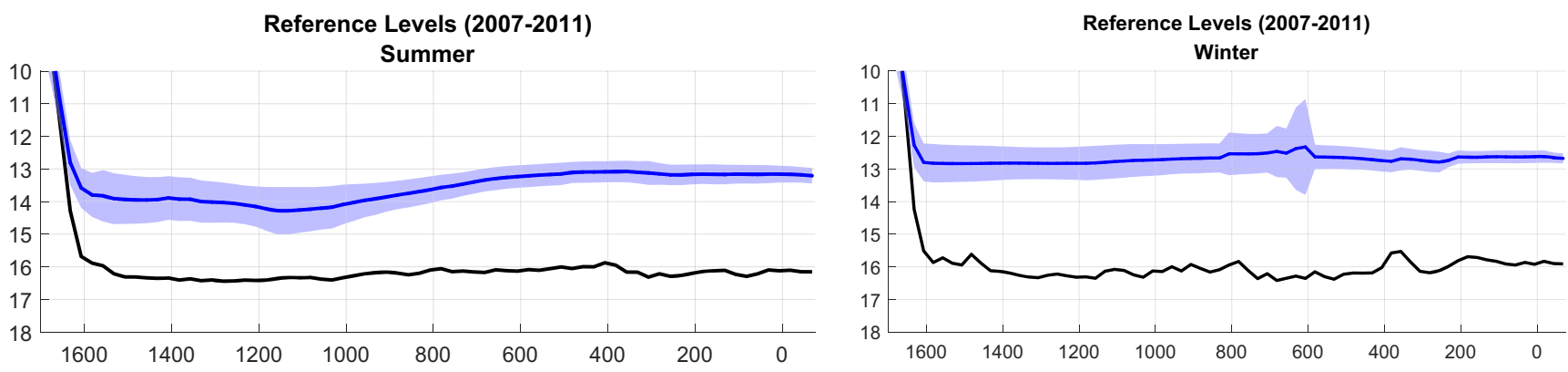

Fig. 12 Seasonal variation of levels in Albert II dock. Mean 210-kHz level ( \pm 1 standard deviation) in blue for summer (left) and winter (right), $33 \mathrm{kHz}$ in black. Values on $x$-axis correspond to the distance along the leading light line (indicated on Fig. 1)

Figure 12 shows the seasonal pattern in the shape of the mud layer in the Albert II dock. Where the mudwater interface is flat in winter, it shows a height variation of $1 \mathrm{~m}$ (max. slope $1 / 400)$ in summer. Seasonal modulation of the strength properties is a possible explanation for this pattern.

Fettweis and Baeye (2015) argue that microbial activity is the main driver of the seasonality in floc size yielding larger flocs in summer than in winter, rather than the seasonality in wind strength and thus wave climate. Further research is needed, however, to investigate the seasonal variations in floc properties inside the harbor (e.g., size and fractal dimension) and to link the floc properties with seasonal variations in settling velocity, sediment input rate, consolidation rate, and strength properties of the bed.

\section{Conclusions}

Data on the vertical position of the mud-water interface was combined with dredging data to calculate the natural depth change of the mud-water interface (Section 3.2). This natural depth change was cross-referenced with data on meteo conditions (waves and freshwater inflow) to study influencing factors. The effect of freshwater inflow on sediment import into the harbor is negligible, and only a slight positive correlation was found between the peak significant wave height and the natural depth change of the mud-water interface.

The data support the hypothesis that mud is transported into the harbor of Zeebrugge through advection of suspended sediment. Most of the sediment import occurs from $2 \mathrm{~h}$ before high water to high water. Sediment import through advection is apparent both in the ADCP backscatter dataset (Section 4.3.2) as in the ensembles based on the OBS dataset (Section 4.3.1). This hypothesis is consistent with the analysis of the sediment exchange mechanisms between the harbor of Zeebrugge and the North Sea presented by Vanlede and Dujardin (2014).
Another siltation mechanism where large quantities of mud are entrained and flow into the harbor as high concentration benthic suspensions (HCBS) has been previously reported for the Port of Rotterdam during storms (Kirby 1988; Winterwerp 1999). However, in our data, we found no evidence of this siltation mechanism transporting mud from the North Sea into the harbor basin, which is consistent with the conclusions of the HCBS measurement program that was executed in the harbor in 2006-2007 (IMDC et al. 2010). It is possible however that gravitational flow of mud layers plays a role in redistributing sediment inside the harbor basin, e.g., sediment flowing gravitationally from CDNB into Albert II dock.

The SPM concentration in the North Sea and in the port close to the entrance is three times higher during spring tide than during neap tide. The same spring-toneap ratio is also found in the sediment influx per tide. Because there is no apparent spring-neap modulation in dredging works, the level of the mud-water interface in Albert II dock typically rises $15 \mathrm{~cm} /$ day during spring tide conditions and falls 5 to $10 \mathrm{~cm} /$ day during neap and average tide conditions.

The seasonality of SPM concentration in the port is consistent with the seasonality observed in the North Sea, with higher SPM concentrations during autumnwinter and lower SPM concentrations during spring-summer. The question to what degree the thickness and density variation of the fluid mud layer are related to differences in the suspended sediment input, to differences in the settling rates of suspended flocs, or to the mud consolidation rate remains open however.

Acknowledgements Data on bathymetry, wave, and currents were gathered and made available by Flemish Hydrography from the Agency for Maritime and Coastal Services - Coastal Division. Additional data of bathymetry and dredging works were provided by the Maritime Access Division of the Ministry of Public Works.

Daily values of freshwater inflow into the port through the Leopoldkanaal and the Schipdonkkanaal were made available by the "Hydrologisch Informatie Centrum" (HIC) of the Ministry of Public Works. 
In situ (ADCP and frame) and remote sensing (satellite) data have been collected by the RBINS-OD Nature. The ship time of the RV Belgica was provided by BELSPO and RBINS-OD Nature.

The first author worked on this paper while affiliated as a guest to Delft University of Technology in the Faculty of Civil Engineering and Geosciences.

The manuscript substantially benefited from the comments of two anonymous reviewers.

Funding information The study was supported by the Maritime Access Division of the Ministry of Public Works of the Flemish Community through contracts 16EF/2011/35 (for the 1-year field study), WL_12_10 (for the analysis of influencing factors), and the MOMO project (for the collection of in situ data outside the harbor and the ADCP transects).

Open Access This article is distributed under the terms of the Creative Commons Attribution 4.0 International License (http:// creativecommons.org/licenses/by/4.0/), which permits unrestricted use, distribution, and reproduction in any medium, provided you give appropriate credit to the original author(s) and the source, provide a link to the Creative Commons license, and indicate if changes were made.

\section{References}

Antea (2015a) Research and monitoring alternative disposal strategy for maintenace dredging in Zeebrugge 2013-2015 (16EF/2011/28). Subreport 1: Factual data reporting of measurements in the port. Ghent, Belgium, 312p (in Dutch). http://documentatiecentrum. watlab.be/imis.php?module $=$ ref \&refid $=252277$

Antea (2015b) Research and monitoring alternative disposal strategy for maintenace dredging in Zeebrugge 2013-2015 (16EF/2011/28). Subreport 3: Study of influencing factors on mud dynamics in the port. Ghent, Belgium, 294p (in Dutch). http://documentatiecentrum. watlab.be/imis.php? module $=$ ref\&refid $=252280$

Antea (2016) Research and monitoring alternative disposal strategy for maintenace dredging in Zeebrugge 2013-2015 (16EF/2011/28). Subreport 6: Orienting study of potential new disposal locations. Ghent, Belgium, 85p (in Dutch). http://documentatiecentrum. watlab.be/imis.php?module $=$ ref\&refid $=255756$

Claeys S, Dumon G, Lanckneus J, Trouw K (2001) Mobile turbidity measurement as a tool for determining future volumes of dredged material in access channels to estuarine ports. Terra et Aqua, $84-$ September 2001

De Maerschalck B, Vanlede J, Mostaert F (2015) Sediment transport model for the Port of Zeebrugge: analysis of the MUMM tripod measurements. Version 3.0. WL Rapporten, 00_067. Flanders Hydraulics Research, Antwerp, Belgium

Delefortrie G, Vantorre M, Verzhbitskaya E, Seynaeve K (2007) Evaluation of safety of navigation in muddy areas through realtime maneuvering simulation. J Waterw Port, Coastal, Ocean Eng 133(2):125-135. https://doi.org/10.1061/(ASCE)0733-950X(2007) $133: 2(125)$

Dujardin A, Ides S, Schramkowski G, De Mulder T, Mostaert F (2009) Haven van Zeebrugge - Optimalisatie maritieme toegankelijkheid: Onderzoek naar de water- en sedimentuitwisseling ter hoogte van de havenmond. Versie 3 _0. WL Rapporten, 843 _ 01. Waterbouwkundig Laboratorium: Antwerpen, België (in Dutch) http://documentatiecentrum. watlab.be/imis.php?module= ref\&refid $=137389$

Dujardin A, Vanlede J, Van Hoestenberghe T, Verwaest T, Mostaert F (2016) Influencing factors on the level of the top of the mud layer in CDNB: Subreport 2-Analysis 1999-2011. Version 5.0. WL
Reports, 00_078. Flanders Hydraulics Research \& Antea Group: Antwerp, Belgium. (In Dutch) http://documentatiecentrum.watlab. be/imis.php? module $=$ ref\&refid $=255141$

Eloot K, Vantorre M, Richter J, Verwilligen J (2009) Development of decision supporting tools for determining tidal windows for deepdrafted vessels. Weintrit, A. (2009). Marine navigation and safety of sea transportation. TransNav 2009:227-234

Fettweis M, Baeye M (2015) Seasonal variation in concentration, size and settling velocity of muddy marine flocs in the benthic boundary layer. J Geophys Res 120:5648-5667. https://doi.org/10.1002/ 2014JC010644

Fettweis M, Baeye M, Francken,F, Lauwaert B, Van den Eynde D, Van Lancker V, Martens C, Michielsen T (2011) Monitoring the effects of disposal of fine sediments from maintenance dredging on suspended particulate matter concentration in the Belgian nearshore area (southern North Sea). Mar Pollut Bull 62(2):258-269. https:// doi.org/10.1016/j.marpolbul.2010.11.002

Fettweis M, Lee BJ (2017) Spatial and seasonal variation of biomineral suspended particulate matter properties in high-turbid nearshore and low-turbid offshore zones. Water 9:694. https://doi.org/10.3390/ w90906

Fettweis M, Nechad B, Van den Eynde D (2007) An estimate of the suspended particulate matter (SPM) transport in the southern North Sea using SeaWiFS images, in situ measurements and numerical model results. Cont Shelf Res 27(10-11):1568-1583. https:// doi.org/10.1016/j.csr.2007.01.017

Fettweis M, Houziaux J-S, Four I, Lancker V, Baeteman C, Mathys M, Eynde D, Francken F, Wartel S (2009) Long-term influence of maritime access works on the distribution of cohesive sediments: analysis of historical and recent data from the Belgian nearshore area (southern North Sea). Geo-Marine Lett 29(5):321-330. https://doi. org/10.1007/s00367-009-0161-7

Fettweis M, Baeye M, Cardoso C, Dujardin A, Lauwaert B, Van den Eynde D, Van Hoestenberghe T, Vanlede J, Van Poucke L, Velez C, Martens C (2016) The impact of disposal of fine-grained sediments from maintenance dredging works on SPM concentration and fluid mud in and outside the harbor of Zeebrugge. Ocean Dyn 66(11):1497-1516. https://doi.org/10.1007/s10236-016-0996-1

Flemish Government (2011) Flow Atlas Harbor of Zeebrugge. Flow measurements in Pas van het Zand and harbor of Zeebrugge. Flemish Government, Ministry of Mobility and Public Works, Agency for Maritime and Coastal Services, Coastal Division, 98p (in Dutch) http://documentatiecentrum.watlab.be/imis.php? module $=$ ref\&refid $=135665$

Holdaway GP, Thorne PD, Flatt D, Jones SE, Prandle D (1999) Comparison between ADCP and transmissometer measurements of suspended sediment concentration. Cont Shelf Res 19(3):421441

International Marine and Dredging Consultants, Deltares, GEMS International, Waterbouwkundig Laboratorium (2010) Long term monitoring of salt and fresh water distribution in the port of Zeebrugge and measurements of high concentration benthic suspensions in the Belgian coastal zone. Subreport 8: Report on the presence of HCBS layers in the Belgian Coastal Zone. Version 3.0. Flanders Hydraulics Research: Antwerp. III, 114 pp. (in Dutch) http://documentatiecentrum. watlab.be/imis.php? $\operatorname{module}=$ ref\&refid=259294

International Marine and Dredging Consultants, Deltares, GEMS International, Waterbouwkundig Laboratorium (2011) Long term monitoring of salt and fresh water distribution in the port of Zeebrugge and measurements of high concentration benthic suspensions in the Belgian coastal zone. Salinity profiling during 20072008 in the harbour of Zeebrugge (I/RA/11292/10.123/BQU). Versie 2.0. Flanders Hydraulics Research: Antwerp. III, 18 + appendices pp (in Dutch). http://documentatiecentrum.watlab.be/imis. php? module=ref\&refid $=207267$ 
Kirby R (1988) High concentration suspension (fluid mud) layers in estuaries. In: Dronkers J, van Leussen W (eds) Physical processes in estuaries. Springer-Verlag, Berlin, pp 463-487

Kirby R (2011) Minimising harbor siltation-findings of PIANC working group 43. Ocean Dyn 61:233-244. https://doi.org/10.1007/ s10236-010-0336-9

Kranenburg C (1998) Dichtheidsstromen, Handleiding college CTwa5302. TU Delft, Faculteit Civiele Techniek en Geowetenschappen, sectie Waterbouwkunde

Lanckneus J, Van Lancker V (2001) Relatie tussen hydro-meteo en sedimentatie in de haven van Zeebrugge. Studiedag "Milieuaspecten van baggerwerken op de Belgische kust.", Gent, 19/12/2001. Vlaams Instituut voor de Zee (VLIZ): Oostende, België

McAnally WH, Friedrichs C, Hamilton D, Hayter E, Shrestha P, Rodriguez H, Sheremet A, Teeter A (2007) Management of fluid mud in estuaries, bays and lakes. Part 1: present state of understanding on character and behaviour. J Hydraul Eng 133:9-22

McAnally WH, Kirby R, Hodge SH, Welp TL, Greiser N, Shrestha P, McGowan D, Turnipseed P (2016) Nautical depth for U. S. Navigable waterways : a review. J Waterw Port Coast Ocean Eng 142(2):1-13. https://doi.org/10.1061/(ASCE)WW.1943-5460. 0000301

Mehta AJ (1991) Understanding fluid mud in a dynamic environment. Geo-Mar Lett 11(3-4):113-118

Mehta AJ, Samsami F, Khare YP, Sahin C (2014) Fluid mud properties in nautical depth estimation. J Waterw Port, ..., (April) 140:210-222. https://doi.org/10.1061/(ASCE)WW.1943-5460.0000228
Merckelbach LM, Kranenburg C (2004) Equations for effective stress and permeability of soft mud-sand mixtures. Géotechnique 54(4): 235-243. https://doi.org/10.1680/geot.2004.54.4.235

PIANC (World Association for Waterborne Transport Infrastructure) (1997) Approach channels, a guide for design, Supplement to Bulletin, No. 95, Brussels, Belgium

Pieters A, Dumon G, Speleers L (2001) Onderzoek naar de ecologische impact van de baggerwerkzaamheden aan de Belgische kust in het kader van MOBAG 2000: chemisch-biologische aspecten

Thorne PD, Hardcastle PJ, Holdaway GP, Born AJ (1994) Analysis of results obtained from a triple frequency acoustic backscatter system for measuring suspended sediments. In: Proceedings of the 6th International Conference on Electronic Engineering in Oceanography, vol 394, pp 83-89

Vanlede J, Dujardin A (2014) A geometric method to study water and sediment exchange in tidal harbors. Ocean Dyn 64(11):1631-1641. https://doi.org/10.1007/s10236-014-0767-9

Winterwerp JC (1999) "On the dynamics of high-concentrated mud suspensions." Ph.D. thesis, technical Univ. of Delft, Delft, Netherlands

Winterwerp JC (2005) Reducing harbor siltation I: methodology. J Waterw Port Coast Ocean Eng 131:258-266. https://doi.org/10. 1061/(ASCE)0733-950X(2005)131:6(258)

Winterwerp JC, de Boer WP (2016) The role of fresh water discharge on siltation rates in harbor basins, in: (2016). Pianc Copedec IX. pp. $228-229$ 